\title{
Analisa Pengaruh Berat Roda Daya terhadap Akselerasi Kendaraan Toyota Kijang 7K
}

\author{
Ratnawati' ${ }^{1}$ Mimin Septiani ${ }^{2}$, Fitria $^{3}$ \\ Jurusan Teknik Mesin Sekolah Tinggi Teknologi Industri Bontang ${ }^{1}$ \\ Jurusan Teknik Kimia Sekolah Tinggi Teknologi Industri Bontang ${ }^{2,3}$ \\ Jl. Brigjen Katamso No. 40, Bontang, Kalimantan Timur, Indonesia ${ }^{1,2,3}$ \\ Email: azahabr@gmail.com¹, hallomimi@technologist.com², tekimfitri@gmail.com³
}

\begin{abstract}
Abstrak
Analisa pengaruh berat roda daya (flywheel) sangatlah berguna dalam dunia otomotif pada kendaraan roda empat khususnya mesin $7 \mathrm{~K}$. Dalam dunia otomotif kita dapat mengetahui kecepatan dan percepatan suatu kendaraan. Tujuan penelitian ini untuk mengetahui perubahan kecepatan kendaraan akibat adanya perubahan berat roda daya dan mengetahui perubahan percepatan kendaraan akibat adanya perubahan berat roda daya dengan berat yang tertentu. Dari hasil perhitungan analisis berat roda daya 95,06 kg dengan putaran maksimum $2800 \mathrm{rpm}$, maka kecepatan kendaraan (v) yang dihasilkan sebesar $64.87 \mathrm{~km} / \mathrm{jam}$ dan pada saat dimensi berat roda daya mengalami pengurangan berat hingga 86,24 kg menghasilkan putaran mesin $2939,23 \mathrm{rpm}$ dan menyebabkan naiknya kecepatan kendaraan (v) 68,05 km/jam. Percepatan kendaraan pada pemakaian roda daya standar dengan berat 95,06 kg dengan putaran maksimum mesin $2800 \mathrm{rpm}$ kendaraan mengalami percepatan $13,161 \mathrm{~m} / \mathrm{s}^{2}$ dan pada saat dimensi berat roda daya mengalami pengurangan berat hingga $86,24 \mathrm{~kg}$ dengan menghasilkan putaran maksimum 2939,23 rpm kendaraan mengalami percepatan 13,246 m/s2 .
\end{abstract}

Kata Kunci: Pengaruh, flywheel, akselerasi, mesin 7K.

\section{Pendahuluan}

Sudah banyak macam cara dan ide kreatif dilakukan untuk meningkatkan teknologi motor bakar. Dari memodifikasi hingga penelitian-penelitian telah dilakukan. Perkembangan teknologi tersebut dari waktu ke waktu terus mengalami perkembangan. Hal ini tentu saja tak lepas dari peran para pakar teknologi yang telah bekerja tanpa mengenal lelah dalam menciptakan dan menyempurnakan temuan-temuan yang diperoleh. Sedemikian pentingnya peranan motor bakar dalam menopang urat nadi kehidupan, khususnya dalam bidang otomotif atau transportasi. Sebagai orang akademis sudah tugas kita untuk ikut serta dalam menciptakan penemuan-penemuan baru yang nantinya dapat meningkatkan dan menyempurnakan teknologi motor bakar tersebut [1].

Kendaraan diharapkan selalu dalam performa yang tinggi dan mesin yang optimal. Kendaraan dengan mesin bensin mempunyai beberapa keuntungan, salah satunya adalah mudah dalam memodifikasi mesin. Modifikasi mesin dilakukan dengan tujuan untuk meningkatkan performa kendaraan. Modifikasi dapat dilakukan pada beberapa bagian. Biasanya dilakukan dengan cara meningkatkan perbandingan kompresi, perbaikan sistem bahan bakar, dan perbaikan sistem pengapian [2].

Flywheel merupakan komponen dari mesin yang mampu menyimpan energi kinetik dari gerak rotasi poros engkol dan bertujuan untuk menghasilkan putaran mesin yang stabil. Flywheel atau roda gila dihubungkan pada ujung poros engkol sebuah mesin yang menerima tenaga putar dari piston selama langkah usaha, yang kemudian akan berkurang akibat langkahlangkah lain, inertia loss, dan juga akibat gesekan. Flywheel berfungsi sebagai suatu lumbung penyimpanan energi, yang mana menyimpan energi saat suplai melebihi kebutuhan dan melepaskannya saat suplai lebih kecil dari kebutuhan yang mana juga 
berguna sebagai kontrol dari terjadinya suatu fluktuasi kecepatan dan mampu mebuat crankshaft berputar secara kontinyu dan terus menerus dan mengakibatkan mesin beroperasi [3].

Kemampuan kendaraan untuk melakukan serta untuk mengangkut beban pada dasarnya adalah kemampuan kendaraan untuk melawan gaya hambat yang ada yaitu gaya hambat angin, gaya hambat tanjakan, gaya inersia, serta gaya gesek yang terjadi pada bagian kendaraan yang bergerak. Kemampuan kendaraan tersebut sangat dipengaruhi oleh kemampuan mesin kendaraan, pemilihan tingkat dan rasio transmisi dan transmisi yang dipakai [4].

Dalam hal ini pemakaian sebuah roda daya (flywheel) akan memungkinkan mesin beroperasi dengan variasi percepatan yang minimum karena roda daya akan bekerja sebagai suatu reservoir untuk menyerap energi yang berkelebihan, dan didistribusikan kembali ketika energi yang disuplai tidak mencukupi untuk beban pada mesin. Jelas bahwa tidak mungkin mendapatkan suatu kecepatan putar pada poros keluaran yang terus menerus secara mutlak jika daya yang disuplai pada laju yang berubah ubah meskipun dengan sebuah roda daya adalah perlu untuk memungkinkan redistribusi energi tersebut. Tetapi, suatu perubahan tertentu dari energi di dalam roda daya, variasi kecepatan dapat diubah sekecil mungkin dengan menggunakan sebuah massa yang besar. Dalam hal ini, perubahan percepatan suatu mesin sangat dipengaruhi oleh massa flywheel.

\section{Tinjauan Pustaka}

Secara umum kinerja traksi kendaraan dapat dibedakan menjadi 3 (tiga) jenis kinerja, yaitu: pertama adalah kemampuan kendaraan untuk melaju serta mengangkut suatu beban. Kedua adalah kemampuan kendaraan untuk membelok dan menjaga kestabilan arahnya, mudah dikendalikan sehingga terhindar dari kecelakaan, ini disebut dengan kestabilan kinerja kestabilan arah kendaraan. Ketiga adalah kemampuan kendaraan membuat pengendara dan penumpang aman dari benturan akibat kecelakaan sehingga pengendara dan penumpang aman dari cedera akibat kecelakaan, kemampuan ini disebut kinerja pengaman kendaraan [5].

\section{Tahanan Rolling}

Tahanan rolling yang terjadi pada ban disebabkan oleh sifat hysterisis ban karena adanya defleksi dari ban. Akibat adanya defleksi ban pada saat rolling, dan sifat material ban yang tidak cepat kembali setelah terdefleksi. Sedangkan koefisien gesek pada berbagai kondisi jalan tergantung pada kecepatan kendaraan [6].

Metode penelitian dengan melakukan variasi tipe ban (ban radial, ban bias), yaw, kontak permukaan jalan (aspal, batu kwarsa, dan beton) dan kecepatan kendaraan untuk memperoleh seberapa besar gaya dorong gabungan tingkatan transmisi pada kendaraan. Hasil penelitian menunjukkan bahwa gaya traksi yang terbesar untuk ketiga kontak permukaan jalan terjadi pada kondisi jalan batu kwarsa dengan menggunakan ban bias, dengan variasi sudut yaw untuk berbagai kondisi bukanlah merupakan faktor dominan yang mempengaruhi traksi kendaraan tetapi dapat mengganggu kestabilan kendaran. Pemilihan tipe ban radial sebagai alternatif untuk konsumsi bahan bakar yang lebih irit dengan tingkat keamanan yang lebih baik (daya cengkeraman baik) dibanding ban bias karena memiliki Fbias $>$ Fradial (konsumsi bahan bakar yang ditransformasi mesin ke roda lebih besar untuk ban bias dibanding ban radial) berkisar $\pm 0,5-2.5 \%$. Hasil eksperimen dari Taborek menghasilkan sebuah rumus dasar dan untuk memprediksi harga koefisien hambatan rolling. Eksperimen ini mengambil tekanan pada ban dan kecepatan kendaraan sebagai parameter pokok yang mempengaruhi hambatan rolling. Harga rata-rata dari koefisien hambatan rolling untuk berbagai jenis ban kendaraan dan berbagai kondisi jalan [7]. 
Tabel 1. Koefisien hambatan rolling untuk berbagai ban dan jalan

\begin{tabular}{c|c|c|c}
\hline \multirow{2}{*}{$\begin{array}{c}\text { Jenis } \\
\text { Kendaraan }\end{array}$} & \multicolumn{3}{|c}{ Permukaan jalan } \\
\cline { 2 - 4 } & Beton & $\begin{array}{c}\text { Keras/ } \\
\text { aspal }\end{array}$ & Pasir \\
\hline $\begin{array}{c}\text { Kendaraan } \\
\text { penumpang }\end{array}$ & 0,0015 & 0,008 & 0,03 \\
\hline Truk & 0,0012 & 0,006 & 0,025 \\
\hline Traktor & 0,0020 & 0,004 & 0,02 \\
\hline
\end{tabular}

Kekasaran permukaan jalan adalah merupakan faktor utama yang mempengaruhi koefisien gesek antara ban dan jalan. Untuk jalan yang kering dengan permukaan yang halus akan memberikan koefisien gesek yang besar antara ban dan jalan, namun sebaliknya jika ia dalam keadaan basah maka akan memberikan koefisien gesek yang kecil.

\section{Gaya Dorong Kendaraan}

Gaya dorong kendaraan juga umum disebutkan sebagai gaya teraksi yang terjadi pada roda penggerek kendaraan untuk melawan segala hambatan pada kendaraan. Hambatan yang harus di lawan oleh gaya dorong tersebut hambatan angin, hambatan rolling, hambatan tanjakan, hambatan beban yang mungkin ditarik oleh kendaraan [8].

Pemilihan roda penggerak juga sangat menentukan gaya traksi maksimum yang dapat dihasilkan dan secara langsung dapat mempengaruhi kinerja traksi kendaraan. Secara umum roda penggerak yang dipilih agar dapat menghasilkan gaya traksi maksimum adalah roda yang menerima gaya normal yang lebih besar. Kendaraan sedan dan sport yang memerlukan kemampuan maneuver yang tinggi lebih cenderung menggunakan roda depan sebagai roda penggerak. Hal ini disebabkan oleh karena kendaraan dengan lebih mudah dikendalikan saat manuver atau belok. Dan lebih menjamin posisi stir, serta dapat dipercepat pada saat belok tanpa mengakibatkan over steer seperti pada kendaraan roda belakang.

3. Transmisi Roda Gigi
Transmisi roda gigi yang secara umum juga dianggap sebagai dive train yang mentranformasikan torsi yang keluar dari mesin sampai ke torsi yang terjadi pada roda penggerak. Semua komponen yang dibutuhkan untuk itu adalah bagian dari transmisi [9].

Umumnya transmisi manual terdiri dari kopling, sistem roda gigi, poros, setelah gigi diferensial, dan poros penggerak. Perbandingan poros mesin dan poros penggerak yang diakibatkan oleh perbandingan gigi transmisi dan gigi diferensial adalah berperan untuk mentransmisikan ke roda penggerak.

Untuk menghasilkan torsi dan gaya dorong pada roda penggerak yang mengecilkan pada kecepatan yang semakin tinggi diperlukan perbandingan yang bertingkat. Sehingga kemampuan transmisi manual untuk mentransformasikan torsi yang dihasilkan oleh mesin menjadi torsi yang dibutuhkan pada roda untuk mendorong kendaraan.

Dengan mengetahui perbandingan gigi untuk tingkat transmisi maka gaya dorong yang dihasilkan dapat dihitung dengan persamaan 1 .

$$
F k v=\frac{M e . I k i d}{r} n
$$

Keterangan :

$\begin{array}{ll}\text { Fkv } & \text { gaya dorong pada roda } \\ & \text { penggerak untuk transmisi } \mathrm{k} \\ & \text { kecepatan kendaraan } \\ \mathrm{M}_{\mathrm{e}}(\mathrm{V}) & =\text { Torsi dari mesin untuk } \\ & \text { kecepatan kendaraan } \mathrm{V} \\ \mathrm{Ik} \quad & =\text { Perbandingan transmisi tingkat } \\ & \text { ke } \mathrm{k} \\ \mathrm{r} \quad & =\text { Jari-jari roda penggerak } \\ \mathrm{n} & =\text { Efisiensi transmisi }\end{array}$

Efisiensi terjadi akibat adanya kehilangan mekanis pada komponen seperti kopling, pasangan gigi, bantalan dan join. Efisiensi yang terjadi pada komponen tersebut dapat dirumuskan sebagai berikut:

- Untuk kopling $\left(\eta_{\mathrm{c}}\right) \quad=98-99 \%$

- Untuk pasangan gigi $\left(\eta_{\mathrm{g}}\right)=95-97 \%$ 
- Untuk bantalan dan join $\left(\eta_{\mathrm{br}}, \eta_{\mathrm{a}}\right)=98-$ $99 \%$

Dari transmisi torsi mesin $\left(\mathrm{M}_{\mathrm{e}}\right)$, terlihat bahwa torsi sebagai fungsi dari putaran mesin. Putaran dari mesin adalah menentukan kecepatan dari kendaraan, dengan demikian maka dapat dicari dari karakteristik torsi mesin sebagai fungsi dari kecepatan kendaraan. Adapun hubungan kecepatan kendaraan dan putaran mesin dapat dihitung dengan persamaan 2 .

$$
V=\frac{2 \cdot \pi \cdot n e \cdot r}{60 \cdot i k \cdot i d}(1-S)
$$

Keterangan :

$\mathrm{V}=$ Kecepatan kendaraan (m/det)

$\mathrm{n}_{\mathrm{e}}=$ Kecepatan putar mesin $(\mathrm{rad} / \mathrm{det})$

$\mathrm{S}=$ slip pada ban kendaraan (2-5\%)

Untuk gaya dorong bersih atau gaya dorong maksimum yang terjadi pada bidang kontak ban dan jalan dengan asumsi koefisien geser tertentu. Gaya dorong bersih $\left(\mathrm{F}_{\mathrm{n}}\right)$ dimaksudkan adalah gaya dorong total dikurangi hambatan rolling dan hambatan aerodinamik, dapat dihitung dengan persamaan 3 .

$$
\mathrm{F}_{\mathrm{n}}=\mathrm{F}-\mathrm{R}_{\mathrm{r}}-\mathrm{R}_{\mathrm{a}}
$$

Pada persamaan 3 kecepatan maksimum yang dapat dicapai kendaraan hanya pada gradibility jalan datar saja.

\section{Karakteristik Laju Kendaraan}

Kinerja laju dari suatu kendaraan sangat erat terkait dengan karakteristik gaya dorong yang dihasilkan oleh kendaraan dan gaya hambat yang dialami oleh kendaraan. Parameter pokok yang sering dipakai untuk menunjukkan kemampuan laju dari kendaraan yaitu:

1. Percepatan kendaraan (a) yang dapat dihasilkan pada setiap kecepatan kendaraan.

2. Waktu yang diperlukan (t) untuk menaikkan kecepatan dari kecepatan awal $\left(\mathrm{V}_{1}\right)$ ke kecepatan yang lebih tinggi $\left(\mathrm{V}_{2}\right)$.

3. Jarak tempuh (s) yang diperlukan untuk menaikkan kecepatan dari $\mathrm{V}_{1}$ ke $\mathrm{V}_{2}$.

\section{Metode Penelitian}

Dalam Penelitian ini waktu yang digunakan berlangsung selama 2 (dua) minggu mulai dari tanggal 5-23 Januari 2010 di Laboratorium Otomotif Balai Latihan Kerja Industri Makassar (BLKI). Penelitian ini dilakukan dengan cara membandingkan akselerasi kendaraan Toyota Kijang $7 \mathrm{~K}$ yang menggunakan komponen roda daya standar dan modifikasi.

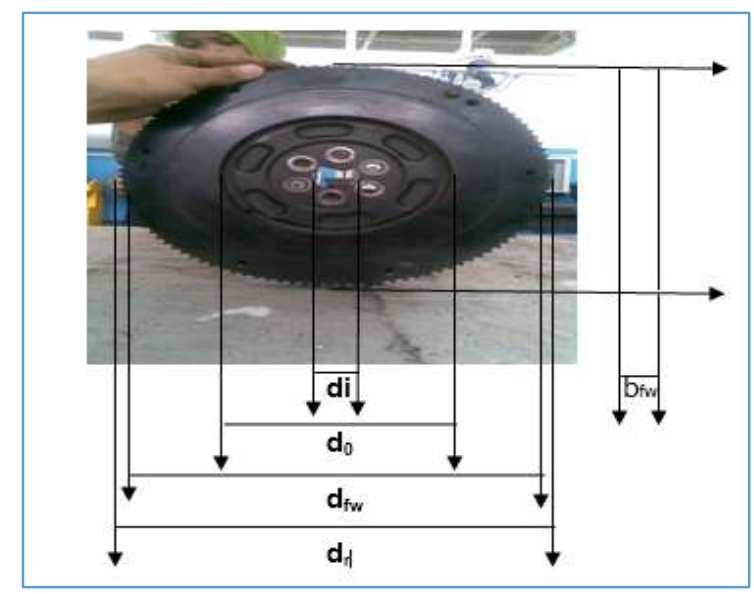

Gambar 2. Komponen Standar Roda Daya

Keterangan:

$$
\begin{array}{lll}
\mathrm{di} & =2,94 \mathrm{~cm} \sim 0,0294 \mathrm{~m} \\
\mathrm{do} & =13,35 \mathrm{~cm} \sim 0,1335 \mathrm{~m} \\
\mathrm{~d}_{\mathrm{fw}} & =26 \mathrm{~cm} \sim 0,260 \mathrm{~m} \\
\mathrm{~d}_{\mathrm{r}} & =27,7 \mathrm{~cm} \sim 0,277 \mathrm{~m} \\
\mathrm{~b}_{\mathrm{fw}} & =3,2 \mathrm{~cm} \sim 0,032 \mathrm{~m} \\
\mathrm{t}_{\mathrm{r}} & =0,915 \mathrm{~cm} \sim 0,00915 \mathrm{~m}
\end{array}
$$

Berat komponen standar

$$
\begin{array}{ll}
\mathrm{m}_{\mathrm{fw}} & =9,7 \cdot 9,8=95,06 \mathrm{~kg} \\
\mathrm{~m}_{\mathrm{r}} & =0,65 \mathrm{~kg}
\end{array}
$$

Data roda daya modifikasi didapatkan dengan mengasumsikan bahwa diameter roda daya tetap namun bobot yang berubah, dengan data sebagai berikut :

$\mathrm{d}_{\mathrm{fw}}=$ Diameter roda daya standar $=, 26 \mathrm{~m}$

$\mathrm{d}_{\mathrm{p}}=$ diameter poros standar $=0,0294 \mathrm{~m}$

$\mathrm{m}_{\mathrm{m}}=$ massa roda daya dimodifikasi $=94,08 \mathrm{~kg}$

Metode yang digunakan dalam menganalisis adalah:

1. Menghitung berat dan dimensi komponen standar

2. Menghitung energi dan kecepatan roda daya 
3. Menghitung kecepatan kendaraan

4. Menghitung percepatan kendaraan

\section{Hasil dan Pembahasan}

Mekanisme roda daya merupakan bagian dari suatu mesin yang bekerja sebagai komponen yang dapat menjaga stabilitas putaran mesin serta berfungsi menyerap energi yang berlebihan, untuk didistribusikan kemudian kembali ketika energi yang disuplai tidak mencukupi untuk beban pada mesin.

Dalam penelitian dan analisis ini roda daya yang digunakan adalah roda daya reservoir untuk menyerap energi yang berkelebihan yang dihasilkan oleh mesin.

Adapun dimensi dan berat komponen standar diperoleh dari hasil pengukuran langsung pada mekanisme yang akan dianalisis dalam kondisi standar.

\section{Kecepatan kendaraan}

1) Kecepatan kendaraan saat gigi 1

$$
\begin{aligned}
V & =\frac{2(3,14) \cdot(2 \cdot 800) \cdot(0,2632)}{60(3,928) \cdot(4,778)} \cdot(1-0,05) \\
& =\frac{4396 \cdot 70336}{1126,07904} \cdot(0,95) \\
& =3,904 \mathrm{~m} / \mathrm{det} \\
& =14,054 \mathrm{~km} / \mathrm{jam}
\end{aligned}
$$

2) Kecepatan kendaraan saat gigi 2

$$
\begin{aligned}
V & =\frac{2(3,14) \cdot(2 \cdot 800) \cdot(0,2632)}{60(2,1449) \cdot(4,778)} \cdot(1-0,05) \\
& =\frac{4396 \cdot 70336}{614,90832} \cdot(0,95) \\
& =7,220 \mathrm{~m} / \mathrm{det} \\
& =25,992 \mathrm{~km} / \mathrm{jam}
\end{aligned}
$$

3) Kecepatan kendaraan saat gigi 3

$$
\begin{aligned}
V & =\frac{2(3,14) \cdot(2 \cdot 800) \cdot(0,2632)}{60(1,397) \cdot(4,778)} \cdot(1-0,05) \\
& =\frac{4396 \cdot 70336}{400,90832} \cdot(0,95) \\
& =10,978 \mathrm{~m} / \text { det } \\
& =39,520 \mathrm{~m} / \text { det }
\end{aligned}
$$

4) Kecepatan kendaraan saat gigi 4

$$
\begin{aligned}
V & =\frac{2(3,14) \cdot(2 \cdot 800) \cdot(0,2632)}{60(1,000) \cdot(4,778)} \cdot(1-0,05) \\
& =\frac{4396 \cdot 70336}{286,68} \cdot(0,95) \\
& =15,336 \mathrm{~m} / \mathrm{det} \\
& =55,209 \mathrm{~km} / \mathrm{jam}
\end{aligned}
$$

5) Kecepatan kendaraan saat gigi 5

$$
\begin{aligned}
V & =\frac{2(3,14) \cdot(2 \cdot 800) \cdot(0,2632)}{60(0,851) \cdot(4,778)} \cdot(1-0,05) \\
& =\frac{4396 \cdot 70336}{243,96468} \cdot(0,95)
\end{aligned}
$$

$$
\begin{aligned}
& =18,021 \mathrm{~m} / \mathrm{det} \\
& =64,875 \mathrm{~km} / \mathrm{jam}
\end{aligned}
$$

\section{Perhitungan percepatan kendaraan}

1) Percepatan kendaraan saat gigi 1

$$
\begin{aligned}
a 1 & =\frac{F k 1}{\gamma m \cdot W} \\
& =\frac{968,46}{5,09.1445} \\
& =13,161 \mathrm{~m} / \mathrm{s}^{2}
\end{aligned}
$$

2) Percepatan kendaraan saat gigi 2

$$
\begin{aligned}
a 2 & =\frac{F k 2}{\gamma m . W} \\
& =\frac{5265,99}{5,09.1445} \\
& =7,159 \mathrm{~m} / \mathrm{s}^{2}
\end{aligned}
$$

3) Percepatan kendaraan saat gigi 3

$$
\begin{aligned}
a 3 & =\frac{F k 3}{\gamma m \cdot W} \\
& =\frac{3420,65}{5,09.1445} \\
& =4,650 \mathrm{~m} / \mathrm{s}^{2}
\end{aligned}
$$

4) Percepatan kendaraan pada saat gigi 4

$$
\begin{aligned}
a 4 & =\frac{F k 4}{\gamma m \cdot W} \\
& =\frac{2431,50}{5,09.1445} \\
& =3,305 \mathrm{~m} / \mathrm{s}^{2}
\end{aligned}
$$

5) Percepatan kendaraan pada saat gigi 5

$$
\begin{aligned}
a 5 & =\frac{F k 5}{\gamma m \cdot W} \\
& =\frac{2056,84}{5,09.1445} \\
& =2,796 \mathrm{~m} / \mathrm{s}^{2}
\end{aligned}
$$

\section{Analisa kecepatan putaran roda daya \\ Pada putaran 2800 rpm dimana} putaran tersebut adalah sebagai putaran maksimum untuk roda daya standar dengan berat $9,7 \mathrm{~kg}$, pada kondisi dimensi berat roda daya dimodifikasikan dengan berat yang dikurangi hingga $8,8 \mathrm{~kg}$ maka terjadi kenaikan putaran sebesar 2939,23 rpm, Jika dibandingkan dengan hasil yang diperoleh ketika massa roda daya standar dengan berat roda daya modifikasi mengalami kenaikan putaran sebesar 136,65 rpm.

Semakin tinggi kecepatan putar tersebut hal ini disebabkan karena beban yang di bawah oleh roda daya ringan, sehingga mengurangi gesekan yang mungkin terjadi akibat gaya gravitasi pada poros bantalan. 


\section{Analisa kecepatan kendaraan}

Kecepatan kendaraan dipengaruhi oleh putaran mesin, semakin bertambahnya putaran mesin roda daya standar dengan berat $9,7 \mathrm{~kg}$ dengan putaran maksimum mesin $2800 \mathrm{rpm}$ kendaraan mengalami kecepatan (v) 39,92 km/jam dan pada saat dimensi berat roda daya mengalami pengurangan berat hingga $8,8 \mathrm{~kg}$ dengan menghasilkan putaran maksimum 41,84 rpm. Jika dibandingkan dengan hasil yang diperoleh ketika massa pada daya standar dengan berat roda daya modifikasi kendaraan mengalami kenaikan kecepatan hingga sebesar $1,92 \mathrm{~km} / \mathrm{jam}$.

\section{Analisa percepatan kendaraan}

Percepatan yang dihasilkan mengalami peningkatan sebanding dengan pengurangan dimensi berat roda daya. Pemakaian roda daya standar dengan berat 9,7 kg dengan putaran maksimum mesin $2800 \mathrm{rpm}$ kendaraan mengalami percepatan $13,161 \mathrm{~m} / \mathrm{s}^{2}$ dan pada saat dimensi berat roda daya mengalami pengurangan berat hingga $8,8 \mathrm{~kg}$ dengan menghasilkan putaran maksimum 2939,23 rpm kendaraan mengalami percepatan $13,246 \mathrm{~m} / \mathrm{s}$.

\section{Kesimpulan}

Berdasarkan hasil pembahasan dapat ditarik kesimpulan bahwa perubahan berat roda daya dapat mempengaruhi kecepatan kendaraan dimana semakin bertambahnya putaran mesin sebagai akibat dari berkurangnya berat roda daya, maka kecepatan kendaraan semakin bertambah, pemakaian roda daya standar dengan berat 95,06 kg dengan putaran maksimum 2800 rpm, kendaraan mengalami kecepatan (v) $64.87 \mathrm{~km} / \mathrm{jam}$ dan pada saat dimensi berat roda daya mengalami pengurangan berat hingga $86,24 \mathrm{~kg}$ menghasilkan putaran mesin 2939,23 rpm dan menyebabkan naiknya kecepatan kendaraan (v) 68,05 $\mathrm{km} / \mathrm{jam}$. Jika dibandingkan dengan hasil yang diperoleh ketika massa roda daya dalam keadaan standar dengan berat roda daya yang telah dimodifikasi, kecepatan bertambah sebesar 3,18 km/jam.
Dengan pengurangan berat roda daya percepatan yang dihasilkan mengalami peningkatan yang sebanding dengan pengurangan dimensi berat roda daya. Pemakaian roda daya standar dengan berat 95,06 kg dengan putaran maksimum mesin $2800 \mathrm{rpm}$ kendaraan mengalami percepatan $13,161 \mathrm{~m} / \mathrm{s}^{2}$ dan pada saat dimensi berat roda daya mengalami pengurangan berat hingga 86,24 $\mathrm{kg}$ dengan menghasilkan putaran maksimum 2939,23 rpm kendaraan mengalami percepatan $13,246 \mathrm{~m} / \mathrm{s}$.

\section{Referensi}

[1]. Widodo, Edi S. (2016) Pengaruh berat roda gila (flywheel) terhadap konsumsi bahan bakar Pada motor diesel stasioner satu silinder. Jurnal Autindo Politeknik Indonusa Surakarta ISSN : 2442-7918 Vol. 1 Nomor 3 Juni.

[2]. Imam, K., 2005, Studi Perbandingan Daya dan Konsumsi Bahan Bakar Antara Pengapian Standar dengan Pengapian Menggunakan Booster pada Mesin Toyota Seri 5K, Universitas Negeri Semarang.

[3]. Rachmawan, A. Putra; I Made Ariana; \& Gerianto. I (2014) Analisa Pengaruh Flywheel dan Firing Order Terhadap Proses Kerja Mesin Diesel. Jurnal Teknik Sistem Perkapalan Vol. 1, No. 1, Fakultas Teknologi Kelautan, Institut Teknologi Sepuluh Nopember

[4]. A. R. Holowenko, Sendi Prapto, Dinamika Pemesinan, Erlangga, 1993

[5]. Amanto, H., Daryanto, 1991. Ilmu Bahan. Penerbit PT. Bumi Aksar.Jakarta 
[6]. Sutantra, I Nyoman (2001), "Teknologi Otomotif", Surabaya, Guna Widya

[7]. J. Taborek, Mechanics. Ohio Publishing Co, 1957

[8]. Sularso, dan Kiyokatsu Suga. 1987. Dasar Perencanaan dan Pemilihan Elemen Mesin. Jakarta: PT. Prandnya Paramita

[9]. PT. Astra International Tbk. Toyota Sales Operation (AUTO 2000) Cabang Rancaekek Bandung. 